\title{
Pathogenetic Relevance of HLA Class II Expressing Thyroid Follicular Cells in Nontoxic Goiter and in Graves' Disease
}

\author{
B. Grubeck-Loebenstein," M. Londel," C. Greenall," K. Pirich, ${ }^{\ddagger}$ H. Kassal, W. Waldhäusl, ${ }^{\ddagger}$ and M. Feldmann* \\ ${ }^{*}$ Charing Cross Sunley Research Centre, London, United Kingdom; ${ }^{\ddagger}$ Department of Medicine I., Division of Clinical \\ Endocrinology and Diabetes Mellitus and 'Department of Surgery II, University of Vienna, Vienna, Austria
}

\begin{abstract}
HLA class II expressing thyroid follicular cells are found not only in classical thyroid autoimmune diseases, such as Graves' disease, but also in presumably nonautoimmune thyroid disorders such as nontoxic goiter. In this study the immunostimulatory function of the HLA class II expressing thyroid follicular cells derived from patients with nontoxic goiter and with Graves' disease was compared by assessing their capacity to stimulate allogeneic and autologous peripheral blood mononuclear cells, as well as cultured intrathyroidal $\mathbf{T}$ lymphocytes. Proliferation of allogeneic peripheral blood mononuclear cells was stimulated by thyroid follicular cells from both nontoxic goiter and Graves' disease thyroids, thus demonstrating that thyroid follicular cells from both disorders are capable of presenting alloantigens. In contrast the proliferation of autologous peripheral blood mononuclear cells was more efficiently stimulated by thyroid follicular cells from Graves' disease than from nontoxic goiter. Cultured intrathyroidal $T$ lymphocytes proliferated specifically in response to autologous HLA class $\mathrm{II}^{+}$thyroid follicular cells in Graves' disease, but not in nontoxic goiter. The responses were dose dependent and HLA class II restricted. Thyroid autoantigen presentation by HLA class II expressing thyroid follicular cells thus only occurs in Graves' disease, suggesting that HLA class II expression on thyroid follicular cells is an essential feature, but by itself not sufficient for the induction of autoimmunity. Additional factors, the possible nature of which is discussed must also be involved.
\end{abstract}

\section{Introduction}

HLA class II molecules are normally expressed on the surface of antigen presenting cells, such as dendritic cells and macrophages, and play an essential role in the induction of immune responses $(1,2)$. The detection of HLA class II expressing thyroid follicular cells (TFC) ${ }^{1}$ in thyroid autoimmune diseases

Presented in part at the International Symposium on Advances in Thyroidology, Cell and Immunobiological Aspects, Lübeck, FRG, October 1986.

Address reprint requests to Dr. B. Grubeck-Loebenstein, Charing Cross Sunley Research Centre, Lurgan Avenue, Hammersmith, London, W6 8LW, UK.

Received for publication 13 February 1987 and in revised form 9 November 1987.

1. Abbreviations used in this paper: GD, Graves' disease; NTG, nontoxic goiter; TFC, thyroid follicular cells.

J. Clin. Invest.

(c) The American Society for Clinical Investigation, Inc.

0021-9738/88/05/1608/07 \$2.00

Volume 81, May 1988, 1608-1614 such as Graves' disease (GD) and Hashimoto's thyroiditis (3) led to the suggestion that this "aberrant" class II expression might result in the activation of thyroid autoreactive lymphocytes and thus be the initiating and/or perpetuating factor of thyroid autoimmune disease (4). The findings that Graves' disease TFC are capable of presenting antigen (5) and are recognized by autologous $T$ lymphocytes, derived from the thyroid gland $(6,7)$ seemed to support this hypothesis.

However, subsequently it was found that HLA class II expressing TFC were also present in thyroid diseases not considered as autoimmune, such as toxic and nontoxic nodular goiter and thyroid carcinoma (8-11). The occurrence of focal lymphocytic infiltrates and of low titer thyroid autoantibodies are also common in these conditions $(8,9,12,13)$. Two alternative explanations of this finding are possible: $(a)$ The above mentioned disorders are autoimmune, which implies that the spectrum of thyroid autoimmune diseases is much wider than hitherto assumed; or $(b)$ that HLA class II expression on TFC may occur without progressing to the induction of autoimmune disease, for which additional factors must be involved.

The validity of these possibilities was checked by comparing the immunostimulatory function of HLA class II expressing TFC in classical autoimmune disease such as GD and in presumably nonautoimmune thyroid disease such as nontoxic goiter (NTG).

\section{Methods}

\section{Patients}

Six patients with nontoxic goiter (five women, one man, aged $56 \pm 15$, range 29-80 yr) and six patients with Graves' disease (5 women, 1 man, aged $35 \pm 10$, range 22-53 yr) were studied. Patients with NTG had longstanding multinodular goiters of gradually increasing size. Radionuclide thyroid scans with ${ }^{99} \mathrm{TC}$ showed an irregular patchy uptake. Serum total thyroxine and triiodothyronine concentrations were within the normal range. Thyroid autoantibodies (against thyroglobulin and thyroid microsomal antigen) were measured with the tanned red cell hemagglutination techniques (Burroughs Wellcome, Beckenham, UK). Antibodies against microsomal antigen were present in two patients (titer 1:400). One of these two had additional antibodies against thyroglobulin (titer 1:320). None of the patients received any thyroid hormone or antithyroid drug treatment. Patients underwent thyroidectomy and were histologically classified as nodular goiter. Lymphocytic infiltration of the thyroid was also assessed on the basis of hematoxylin-eosin staining.

Patients with GD had small diffuse goiters and two had mild endocrine ophthalmopathy. Thyroid scans showed a diffusely high uptake of radionuclide characteristic of GD. All patients had clinical and laboratory evidence of severe hyperthyroidism at the time of diagnosis. Thyroid autoantibodies against thyroglobulin were present in two patients (titers 1:40 and 1:320) and against thyroid microsomal antigen in five patients (titers range: 1:1,600-1:6,400). All patients underwent thyroidectomy within 18 mo after diagnosis for recurrent hyperthyroidism in spite of continuous antithyroid drug treatment. At the time 
of surgery patients were euthyroid under low doses of either methimazole or prothiucil. In all cases the histological diagnosis was toxic diffuse goiter.

\section{Preparation of thyroid tissue}

$5 \times 5 \mathrm{~mm}$ tissue blocks were snap frozen in liquid nitrogen and $5-\mu \mathrm{m}$ frozen cryostat sections were cut from each sample. Sections were fixed in acetone for $5 \mathrm{~min}$. The degree of in vivo HLA class II expression on TFC in the individual patients was then studied by immunofluorescence staining as described below using a monoclonal anti-HLA-DR antibody (Becton Dickinson \& Co., Oxnard, CA) directed against the nonpolymorphic region of the DR molecule.

The remaining thyroid tissue was dispersed with collagenase (type IV; Cooper Biomedical, Malvern, PA, $5 \mathrm{mg} / \mathrm{ml}$, in RPMI $1640 \mathrm{me}-$ dium containing $15 \%$ fetal calf serum; Gibco Laboratories, Paisley, Scotland) for $3 \mathrm{~h}$, and pipetted through a $200-\mu \mathrm{m}$ mesh. The red blood cells were lysed with an ammonium chloride buffer. The resulting cells were either cryopreserved in liquid nitrogen or used directly. Further separations were performed as follows.

TFC. Cells were incubated in RPMI (supplemented with 15\% FCS, $100 \mathrm{U} / \mathrm{ml}$ penicillin, and $100 \mu \mathrm{g} / \mathrm{ml}$ streptomycin) in $25 \mathrm{~cm}^{2}$ flasks (Becton Dickinson) at $37^{\circ} \mathrm{C}$ in $95 \%$ air $/ 5 \% \mathrm{CO}_{2}$ and $95 \%$ humidity for $24 \mathrm{~h}$. Nonadherent cells were then removed and processed as described below. Macrophages were mostly nonadherent after $24 \mathrm{~h}$ incubation and the few adherent ones could be removed by vigorous pipetting. The remaining adherent cells were removed from the plastic support by a 10 -min exposure to trypsin (Gibco trypsin solution, $0.25 \%$ ) and washed twice. The cell population thus obtained was identified as TFC (purity $>95 \%$ ) by staining with a serum of a patient with GD containing a high titer of antimicrosomal antibodies as previously described (6). Macrophage contamination was estimated as $1.2 \pm 1.74 \%$ by immunofluorescence staining as described below using the monoclonal antibody anti-Leu M3 (Becton Dickinson), which is specific for mature macrophages and monocytes. In two of the patients of each group TFC were additionally stained with anti HLA-DR monoclonal antibody (Becton Dickinson). This was done before and after exposure to recombinant human interferon- $\gamma$ (IFN- $\gamma$; Boehringer Ingelheim, Vienna, Austria; $50 \mathrm{U} / \mathrm{ml}$ for $3 \mathrm{~d}$ in RPMI 1640 containing $2.5 \%$ human serum).

Macrophage-enriched population. The nonadherent cells that had been removed after $24 \mathrm{~h}$ incubation of dispersed thyroid tissue consisted of infiltrating mononuclear cells and nonattached, mainly dead TFC. They were in most cases contaminated with colloid droplets. Dead cells were digested with trypsin and colloid removed by Percoll gradient centrifugation ( $d$ 1.039; Pharmacia, Uppsala, Sweden). The resulting cells were reincubated in RPMI containing 15\% FCS and antibiotics for another 3-12 h. Nonadherent cells were then removed by gentle washing and processed as described below. The reattached cells consisted of $64 \pm 21 \%$ Leu $\mathrm{M}^{+}$cells. In order to be able to estimate the effect of contaminating macrophages in TFC cultures this macrophage-enriched population, which will be referred to as "thyroid macrophages," was used as an internal control in experiments evaluating the antigen presentation capacity of TFC.

$T$ lymphocytes and preparation of $T$ cell lines. In two patients with NTG (patients $E$ and F had been selected on the basis of the presence of thyroid autoantibodies) and two with GD (patients D and E), "expanded" intrathyroidal T lymphocyte lines were studied: nonadherent cells that had been separated from macrophages as described above were reincubated in RPMI supplemented with $10 \%$ human serum and antibiotics and purified recombinant IL-2 $(0.02 \mu \mathrm{g} / \mathrm{ml}$, Sandoz, Vienna, Austria) for $1 \mathrm{wk}$ to select for in vivo activated T cells. These were nonspecifically expanded with anti CD3 antibody (OKT3, 0.03 $\mu \mathrm{g} / \mathrm{ml}$; American Type Culture Collection (ATCC), Rockville, MD), which has been shown to stimulate $T$ cell growth while retaining antigen specificity (14). OKT3 was added to the cell lines together with irradiated (3,000 rad) autologous peripheral blood mononuclear cells as feeders every $7 \mathrm{~d}$ and IL-2 $(0.02 \mu \mathrm{g} / \mathrm{ml})$ was added every $3 \mathrm{~d}$. This procedure has been extensively used in our laboratories and permits growth of $\mathrm{CD}^{+}$and $\mathrm{CD}^{+} \mathrm{T}$ cells, and antigen specificity has been shown to be maintained for over 3 mo in the absence of antigenic stimulation. After 4 wk of culture the cell lines thus obtained (lines N5, N6, GD2, and GD4) were analyzed for IFN- $\gamma$ production, cell surface markers, and antigen specificity.

\section{Interferon- $\gamma$ assay}

Supernatants were collected and assayed for IFN- $\gamma$ with an immunoradiometric assay (Boots Celltech, Nottingham, UK; 'SUCROSEP' IFN- $\gamma$ IRMA). IFN- $\gamma$ was expressed as $U / \mathrm{ml} / 10^{6}$ cells by reference to a standard curve performed in each assay.

\section{Preparation of PBMC}

Peripheral blood mononuclear cells were isolated from heparinized blood by Ficoll-Hypaque density gradient centrifugation (Pharmacia) and washed twice.

\section{Immunofluorescence}

Cells and sections were incubated for $30 \mathrm{~min}$ with the respective monoclonal antibodies. T cell lines were stained with OKT3 (pan T cells), OKT4 (helper/inducer T cells), OKT8 (cytotoxic/suppressor T cells, all obtained from the ATCC) and Leu 11 (to detect natural killer cells, Becton Dickinson), washed three times and incubated for another 30 min with an FITC conjugated rabbit anti mouse IgG (Southern Biotechnology, Birmingham, AL). After another three washes cell suspensions were analyzed on a Becton-Dickinson fluorescence activated cell sorter (FACStar). Controls were either unstained or treated with the second layer. 5,000 scatter gated cells were analyzed in each sample. The frequency and fluorescence profile of the cells was determined with logarithmic signal amplifiers. When, as in the case of TFC and thyroid macrophages, only low cell numbers were available, cells were counted in a Westergen chamber under a Leitz fluorescence microscope and the number of positive cells was expressed as a percentage of the total cell number per 16 fields. Tissue sections were also studied under a Leitz fluorescence microscope and the numbers of HLA-DR ${ }^{+}$ TFC were evaluated semiquantitatively $[(+)$ few cells, $(++)$ numerous, $(+++)$ very numerous].

\section{Proliferation assays on $P B M C$}

TFC, thyroid macrophages and PBMC were irradiated with 3,500 rad using a cesium source $\left({ }^{137} \mathrm{CS}\right.$, Gammator B; Isomedix Inc., Parsippany, $\mathrm{NJ}$ ) and used as stimulator cells in proliferation assays. TFC and thyroid macrophages were used $(a)$ without pretreatment and $(b)$ in order to guarantee maximal HLA class II expression, after previous exposure to recombinant human interferon- $\gamma$ as described above. Autologous as well as allogeneic PBMC were used as responder cells. In the allogeneic system, PBMC of HLA-DR mismatched normal blood donors were used. $10^{4}$ presenter cells were co-cultured in triplicate with $10^{5}$ responder cells in RPMI containing 10\% human serum in 96 well flat bottom plates. After $7 \mathrm{~d}$ of co-incubation, cultures were pulsed with 1 $\mu \mathrm{Ci}\left[{ }^{3} \mathrm{H}\right]$ thymidine (Amersham Corp., Amersham, UK) and proliferation was estimated after $12 \mathrm{~h}$ by scintillation counting. Counts per minute were expressed as means of triplicate cultures. TFC or thyroid macrophages without PBMC and PBMC only were incubated with $\left[{ }^{3} \mathrm{H}\right]$ thymidine as controls. The sum of the control uptakes (TFC/thyroid macrophages control + PBMC control) was considered as background. In view of the variations of background levels within the various cell populations stimulation was additionally expressed as stimulation indices $=$ [stimulation $(\mathrm{cpm})$ minus background $(\mathrm{cpm})] /$ background (cpm). Stimulated and background cpm were compared by Student's $t$ test.

\section{Autoantigen recognition assays}

$T$ cell lines were screened for recognition of autoantigens on autologous TFC, or thyroid macrophages as autologous HLA class II expressing, thyroid associated, but non-TFC control cells. As for peripheral PBMC T cells were cultured in triplicate and used at a constant number of $10^{5} /$ well. TFC $\left(10^{4}\right.$ cells/well $)$ were used with and without 
pretreatment with IFN- $\gamma(50$ and $500 \mathrm{U} / \mathrm{ml})$. Macrophages $\left(10^{4}\right.$ cells/ well) were always prestimulated with IFN- $\gamma(50 \mathrm{U} / \mathrm{ml})$. For TFC limited dose-response curves $\left(3 \times 10^{4}, 10^{4}\right.$, and $3 \times 10^{3}$ TFC per well $)$ were performed. Two cell lines (N5 and GD4) were screened for recognition of allogeneic (DR mismatched) TFC and the two GD lines were assayed for recognition of autologous TFC after the addition of a cocktail of antibodies against HLA class II [purified anti-DR L-243 (HB 55; ATCC) -DP (B7/21; I. Trowbridge, La Jolla, CA) and -DQ (TU22; A. Ziegler, Immunology Department, Medinsky Klinik, Tübingen, West Germany) antibodies, $1 \mu \mathrm{g} / \mathrm{ml}$ each]. Antigen presenting cells were always irradiated with 3,500 rad before use. After $4 \mathrm{~d}$ of co-culture of presenter and responder cells, proliferation assays were performed as described for PBMC.

\section{Statistics}

Proliferation in the different patient groups was expressed as medians and range. Groups were compared by Wilcoxon's rank sum tests on unpaired data. Comparison within the groups (stimulation induced by untreated vs. interferon $\gamma$ pretreated presenting cells) was done by Wilcoxon's rank sum tests on paired data.

\section{Results}

In vivo expression of HLA-class II antigens on TFC. Studies of tissue sections showed that HLA class II expressing TFC were present in all patients of the two groups, although the numbers of positive cells tended to be higher in GD than in NTG (Table I). GD patient B had fewer HLA class II expressing TFC than the other GD patients. HLA class II expression on TFC was always associated with a lymphocytic infiltration of the thyroid gland, although the number of infiltrating lymphocytes was low in two of the patients with NTG (patients A and D) and in one patient with GD (patient B). This GD patient also did not have thyroid autoantibodies. All other GD patients had high titer antibodies against thyroid microsomal antigen and two also had low titer antithyroglobulin antibodies. Thyroid autoantibodies could not be detected in 4/6 NTG patients, but low titer anti-microsomal antibodies were present in two patients, one of whom (NTG patient F) had additionally low titer antithyroglobulin antibodies. This patient had the most marked lymphocytic infiltration of the thyroid gland within the NTG group.

In vitro induction of HLA-class II antigens on TFC with $I F N-\gamma$. Exposure of TFC suspensions to IFN- $\gamma(50 \mathrm{U} / \mathrm{ml}$ for 3 d) resulted in HLA class II expression in over $80 \%$ of the cells in all four patients studied (Table II). HLA class II induction did not differ between patients with NTG and with GD and did not depend on the degree of basal HLA class II expression.

Stimulation of allogeneic PBMC. Proliferation of allogeneic PBMC in response to stimulation with untreated TFC did not differ significantly between NTG and GD (Table III). Counts per minute ranged from 831 to 7,837 (median 1,794 ) in NTG and from 334 to 11.803 (median 6,832) in GD. Significant stimulation (stimulation versus background: $P<0.05$ ) occurred in four patients of each group. After pretreatment of TFC with IFN $\gamma$, counts per minute ranged from 1,425 to 10,764 (median 2,345) in NTG and from 472-12,372 (median 6,351 ) in GD. IFN- $\gamma$ thus induced an enhancement of the response in NTG $(P<0.01)$, but not in GD. The macrophage-enriched control population induced proliferation of allogeneic PBMC in all patients with GD, but only in two of the six with NTG (difference between disease groups: $P<0.05$ ). Counts per minute ranged from 449 to 4,277 (median 1,316 ) in NTG and from 1,116-5,370 (median 3,104) in GD. In NTG stimulation could be increased $(P<0.01)$ by pretreatment of macrophages with IFN- $\gamma$, leading to significant responses in $4 / 6$ patients $(544-9,294$, median $2,642 \mathrm{cpm})$. No such effect of exogenous IFN- $\gamma$ could be observed in GD. Stimulation with patients PBMC induced a stronger response than stimulation with TFC or thyroid macrophages in both groups. Counts per minute ranged from 4,602-28,427 (median 15,392) in NTG and from 13.145 to 56.282 (median 22.648) in GD. Although counts per minute did not differ between disease groups, the respective stimulation indices were significantly higher in NTG than in GD $(P<0.01)$.

Stimulation of autologous PBMC. Graves' disease TFC stimulated autologous PBMC more efficiently than nontoxic goiter TFC (comparison of stimulation indices: $P<0.05$; Table IV). Counts per minute ranged from 307 to 3,049 (median 1,323) in NTG and from 1,124 to 11.748 (median 4,647) in GD. Significant responses were observed in all but one patient with GD (patient B). This patient had no thyroid autoantibodies, a very moderate lymphocytic infiltration of the thyroid gland and only few HLA class $\mathrm{II}^{+}$TFC at the time of surgery and may have been in remission. Special attention was thus paid to the question, whether in NTG TFC from patients in whom the presence of thyroid autoantibodies might suggest

Table I. HLA Class II Expression on Thyroid Follicular Cells, Thyroid Lymphocytic Infiltration, and Thyroid Autoantibodies in Patients with Nontoxic Goiter and Graves' Disease

\begin{tabular}{|c|c|c|c|c|c|c|c|c|c|c|c|c|}
\hline & \multicolumn{6}{|c|}{ Nontoxic goiter patients } & \multicolumn{6}{|c|}{ Graves' disease patients } \\
\hline & A & B & C & D & $\mathbf{E}$ & $\mathbf{F}$ & A & B & C & $\mathbf{D}$ & $\mathbf{E}$ & $\mathbf{F}$ \\
\hline \multicolumn{13}{|l|}{ HLA class II expression on thyroid } \\
\hline follicular cells & + & ++ & ++ & + & ++ & + & ++ & + & ++ & ++ & +++ & ++ \\
\hline \multicolumn{13}{|l|}{ Lymphocytic infiltration of the thyroid } \\
\hline gland & + & ++ & ++ & + & ++ & +++ & ++++ & + & +++ & +++ & ++++ & +++ \\
\hline Autoantibodies against thyroglobulin & $\mathrm{Neg}$ & $\mathrm{Neg}$ & $\mathrm{Neg}$ & $\mathrm{Neg}$ & $\mathrm{Neg}$ & $1: 320$ & $1: 40$ & Neg & Neg & $1: 320$ & Neg & Neg \\
\hline Autoantibodies against microsomal antigen & Neg & Neg & Neg & Neg & $1: 400$ & $1: 400$ & $1: 1600$ & Neg & $1: 6400$ & $1: 6400$ & $1: 3200$ & $1: 1600$ \\
\hline
\end{tabular}

* + Few HLA class II expressing thyroid follicular cells/Few infiltrating lymphocytes. ++ Numerous HLA class II expressing thyroid follicular cells/Small lymphocytic aggregates. +++ Very numerous HLA class II expressing thyroid follicular cells/Big lymphocytic aggregates. ++++ Extensive lymphocytic infiltrate. 
Table II. Percentage of HLA-DR Positive Thyroid Follicular Cells in Cell Suspensions before and after Culture with Interferon- $\boldsymbol{\gamma}^{*}$

\begin{tabular}{lrrrrrr}
\hline & \multicolumn{2}{c}{ Nontoxic goiter } & & \multicolumn{2}{c}{ Graves' disease } \\
& Patient no. & B & C & & B & D \\
\hline Basal & $10 \%$ & $25 \%$ & & $8 \%$ & $38 \%$ \\
IFN- $\gamma 50 \mathrm{U} / \mathrm{ml}$ for 3 d & $89 \%$ & $95 \%$ & & $82 \%$ & $90 \%$
\end{tabular}

* The number of fluorescent cells in a total of 100-200 TFC was counted and expressed as percentage.

the loss of self-tolerance to thyroid antigens (patients E and F) were more efficient stimulators of autologous PBMC than TFC from autoantibody negative patients (patients A-D). However, PBMC proliferation in response to autologous TFC did not differ between NTG patients with and without thyroid autoantibodies and no antibodies against thyroglobulin or microsomal antigen were found in the two NTG patients in whom significant proliferative responses to autologous TFC were observed (patients A and D). As in the allogeneic system, pretreatment of TFC with IFN- $\gamma$ did not induce further stimulation in GD, but enhanced the responses in NTG $(P<0.01$; 310-4880, median $2745 \mathrm{cpm}$ ), inducing significant stimulation of autologous PBMC in 3 of the patients. Although this might suggest that in some of the NTG patients thyroid autoantigen recognition could be induced by stimulation of HLA-class II expression, it seems more likely that interferon $\gamma$ treatment of the presenting cells resulted in the activation of HLA class II reactive autologous MLR clones. Stimulation of autologous PBMC by thyroid macrophages gave varied results in both groups. Stimulation was observed in 2/5 patients with GD and in 1/6 with NTG. Counts per minute ranged from 734 to 1298 (median 1096) in NTG and from 775 to 1,531 (median 873) in GD. IFN- $\gamma$-treated macrophages induced responses in 3/5 cases in GD and in 2/5 in NTG.
Phenotyping and IFN- $\gamma$ production of expanded intrathyroidal lymphocytes. Intrathyroidal lymphocytes from GD and NTG patients responded and increased in number equally well upon culture with IL-2 and anti-CD3, although the initial numbers of infiltrating lymphocytes tended to be lower in NTG (NS). After 4 wk of culture sufficient cells were available for analysis. All four lines consisted predominantly of $T$ cells of the helper/inducer phenotype (OKT4 $4^{+}$; Table V). The percentage of $\mathrm{OKT}^{+}$suppressor/cytotoxic $\mathrm{T}$ cells ranged between 6 and $30 \%$. It varied among the patients, but not between the diseases. In both disorders low percentages of Leu $11^{+}$cells were found. IFN- $\gamma$ was detected in the supernatants of all four lines. The concentrations observed were not significantly different in NTG and GD (Table V).

Autoantigen recognition by expanded intrathyroidal $T$ lymphocytes. When screened for their capacity to recognize autologous TFC, T cell lines from patients with GD gave a marked proliferative response [Fig. 1; lines GD4 and GD2 (derived from GD patients D and E); background stimulation 560 and $543 \mathrm{cpm}$, respectively]. No such response was observed with the lines from NTG [lines N5 and N6; background stimulation: 1,855 and $518 \mathrm{cpm}$, respectively], although the two patients from whom the lines derived (NTG patients E and F) had both thyroid autoantibodies as well as a lymphocytic infiltration of the thyroid gland. No increase in stimulation could be detected by pretreatment of TFC of either NTG or GD with two different doses of IFN- $\gamma$ (Fig. 1). The responses observed in GD were HLA class II restricted, as they could be blocked by addition of a mixture of anti-HLA class II antibodies recognizing DR, DP, and DQ. None of the four $T$ cell lines proliferated in response to IFN- $\gamma$ treated autologous thyroid macrophages (background stimulation: 105-520 cpm, median 291) and there was no response to allogeneic (DR mismatched) TFC (background stimulation: 1,013 and 1,057 cpm, respectively). When stimulation of the lines was tested using varied numbers of TFC it could be shown that the responses observed in GD lines were dependent on the respective numbers of TFC used (Fig. 2; background stimulation: 3

Table III. Proliferation of Allogeneic PBMC after Stimulation with Thyroid Follicular Cells, Thyroid Macrophages or PBMC: $\left[{ }^{3} \mathrm{H}\right]$ Thymidine Uptake (cpm) after $7 \mathrm{~d}$ of Coculture (Stimulation Indices Are Given in Parentheses)

\begin{tabular}{|c|c|c|c|c|c|c|c|c|c|c|c|c|c|c|}
\hline \multirow[b]{2}{*}{ Stimulator } & \multicolumn{6}{|c|}{ Nontoxic goiter patients } & \multirow[b]{2}{*}{ Median } & \multicolumn{6}{|c|}{ Graves' disease patients } & \multirow[b]{2}{*}{ Median } \\
\hline & $\mathbf{A}$ & B & C & D & $\mathbf{E}$ & $\mathbf{F}$ & & $\mathbf{A}$ & B & $\mathbf{C}$ & D & $\mathbf{E}$ & $\mathbf{F}$ & \\
\hline Background $1^{*}$ & 378 & 415 & 1034 & 402 & 642 & 1073 & 529 & 237 & 2023 & 1082 & 1406 & 1398 & 1390 & 1402 \\
\hline TFC $^{\text {NS }}$ & $\begin{array}{c}831 \\
(1.20)\end{array}$ & $\begin{array}{l}1469 \\
\left(2.54^{8}\right)\end{array}$ & $\begin{array}{c}7837 \\
\left(6.58^{8}\right)\end{array}$ & $\begin{array}{r}888 \\
(1.21)\end{array}$ & $\begin{array}{l}2118 \\
\left(2.3^{5}\right)\end{array}$ & $\begin{array}{c}4013 \\
\left(2.74^{8}\right)\end{array}$ & $\begin{array}{c}1794 \\
(2.42)\end{array}$ & $\begin{array}{r}334 \\
(0.41)\end{array}$ & $\begin{array}{c}3783 \\
(0.87)\end{array}$ & $\begin{array}{r}11803 \\
\left(5.55^{8}\right)\end{array}$ & $\begin{array}{c}9195 \\
\left(5.54^{8}\right)\end{array}$ & $\begin{array}{c}7909 \\
\left(5.28^{8}\right)\end{array}$ & $\begin{array}{c}5755 \\
\left(3.14^{8}\right)\end{array}$ & $\begin{array}{r}6832 \\
(4.21)\end{array}$ \\
\hline $\mathrm{TFC} \pm \gamma \mathrm{IFN}^{\mathrm{NS}}$ & $\begin{array}{l}1425 \\
\left(2.77^{\natural}\right)\end{array}$ & $\begin{array}{l}2287 \\
\left(4.51^{8}\right)\end{array}$ & $\begin{array}{l}10764 \\
\left(9.41^{8}\right)\end{array}$ & $\begin{array}{c}2407 \\
\left(4.99^{8}\right)\end{array}$ & $\begin{array}{c}2324 \\
\left(2.62^{8}\right)\end{array}$ & $\begin{array}{l}5150 \\
\left(3.8^{8}\right)\end{array}$ & $\begin{array}{l}2345 \\
(4.16)\end{array}$ & $\begin{array}{r}472 \\
(0.99)\end{array}$ & $\begin{array}{r}5118 \\
(1.53)\end{array}$ & $\begin{array}{r}11803 \\
\left(5.55^{\S}\right)\end{array}$ & $\begin{array}{l}12372 \\
\left(7.8^{5}\right)\end{array}$ & $\begin{array}{c}6850 \\
\left(3.9^{8}\right)\end{array}$ & $\begin{array}{c}5852 \\
\left(3.21^{8}\right)\end{array}$ & $\begin{array}{c}6351 \\
(3.55)\end{array}$ \\
\hline Background 2** & 394 & 462 & 981 & 763 & 259 & 873 & 612 & 988 & 731 & 1395 & 465 & 183 & 512 & 621 \\
\hline Thyroid macrophages" & $\begin{array}{c}449 \\
(0.14)\end{array}$ & $\begin{array}{c}845 \\
(0.83)\end{array}$ & $\begin{array}{c}4277 \\
\left(3.36^{8}\right)\end{array}$ & $\begin{array}{r}1786 \\
(1.39)\end{array}$ & $\begin{array}{r}458 \\
(0.77)\end{array}$ & $\begin{array}{c}3841 \\
\left(3.4^{8}\right)\end{array}$ & $\begin{array}{c}1316 \\
(1.08)\end{array}$ & $\begin{array}{c}3092 \\
\left(2.13^{6}\right)\end{array}$ & $\begin{array}{r}3187 \\
\left(3.36^{8}\right)\end{array}$ & $\begin{array}{r}5370 \\
\left(2.85^{\S}\right)\end{array}$ & $\begin{array}{c}3115 \\
\left(5.07^{5}\right)\end{array}$ & $\begin{array}{c}1116 \\
\left(5.19^{8}\right)\end{array}$ & $\begin{array}{r}2662 \\
\left(4.2^{8}\right)\end{array}$ & $\begin{array}{c}3104 \\
(3.78)\end{array}$ \\
\hline $\begin{array}{l}\text { Thyroid macrophages } \\
+\gamma \text { IFN }^{N S}\end{array}$ & $\begin{array}{c}957 \\
(1.43)\end{array}$ & $\begin{array}{l}2721 \\
\left(4.89^{8}\right)\end{array}$ & $\begin{array}{c}9254 \\
\left(8.04^{6}\right)\end{array}$ & $\begin{array}{c}2563 \\
\left(2.36^{8}\right)\end{array}$ & $\begin{array}{r}544 \\
(1.10)\end{array}$ & $\begin{array}{c}4714 \\
\left(4.4^{\delta}\right)\end{array}$ & $\begin{array}{c}2642 \\
(3.38)\end{array}$ & $\begin{array}{c}3141 \\
\left(2.18^{\delta}\right)\end{array}$ & $\begin{array}{l}4021 \\
\left(4.5^{\S}\right)\end{array}$ & $\begin{array}{r}5399 \\
\left(2.87^{6}\right)\end{array}$ & $\begin{array}{l}3581 \\
\left(6.7^{\S}\right)\end{array}$ & $\begin{array}{r}842 \\
\left(3.6^{8}\right)\end{array}$ & $\begin{array}{r}2355 \\
\left(3.6^{8}\right)\end{array}$ & $\begin{array}{c}3361 \\
(3.6)\end{array}$ \\
\hline Background $3^{\ddagger}$ & 188 & 193 & 1145 & ND & ND & 1134 & 664 & ND & 1441 & ND & 4004 & 1420 & 1220 & 1431 \\
\hline PBMC" & $\begin{array}{c}6046 \\
\left(31.15^{\S}\right)\end{array}$ & $\begin{array}{r}4602 \\
\left(22.8^{8}\right)\end{array}$ & $\begin{array}{c}24738 \\
\left(20.53^{8}\right)\end{array}$ & ND & ND & $\begin{array}{c}28427 \\
\left(24.07^{\S}\right)\end{array}$ & $\begin{array}{c}15392 \\
(21.67)\end{array}$ & ND & $\begin{array}{l}13145 \\
\left(8.1^{8}\right)\end{array}$ & ND & $\begin{array}{c}56282 \\
\left(13.06^{\delta}\right)\end{array}$ & $\begin{array}{c}25079 \\
\left(16.6^{8}\right)\end{array}$ & $\begin{array}{c}20216 \\
\left(15.85^{5}\right)\end{array}$ & $\begin{array}{c}22648 \\
(14.32)\end{array}$ \\
\hline
\end{tabular}

* Background 1, cpm of TFC and of PBMC cultured separately. ** Background 2, cpm of thyroid macrophages and of PBMC cultured separately. ${ }^{\ddagger}$ Background

3, cpm of autologous and allogeneic PBMC cultured separately. "Level of significance between disease groups $P<0.05$ (comparison of stimulation indices).

Significant difference between stimulation and background $P<0.05$. 
Table IV. Proliferation of Autologous PBMC after Stimulation with Thyroid Follicular Cells or Thyroid Macrophages: $\left[{ }^{3}\right.$ H]Thymidine Uptake (cpm) after 7 of Culture (Stimulation Indices Are Given in Parentheses)

\begin{tabular}{|c|c|c|c|c|c|c|c|c|c|c|c|c|c|c|}
\hline \multirow[b]{2}{*}{ Stimulator } & \multicolumn{6}{|c|}{ Nontoxic goiter patients } & \multirow[b]{2}{*}{ Median } & \multicolumn{6}{|c|}{ Graves' disease patients } & \multirow[b]{2}{*}{ Median } \\
\hline & A & B & C & D & $\mathbf{E}$ & $\mathbf{F}$ & & A & B & C & D & $\mathbf{E}$ & $\mathbf{F}$ & \\
\hline Background $1^{*}$ & 484 & 279 & 1326 & 728 & 428 & 1836 & 606 & 267 & 1000 & 1068 & 1673 & 2244 & 1001 & 1035 \\
\hline TFC" & $\begin{array}{l}1800 \\
\left(2.72^{8}\right)\end{array}$ & $\begin{array}{r}307 \\
(0.10)\end{array}$ & $\begin{array}{r}3049 \\
(1.30)\end{array}$ & $\begin{array}{c}2557 \\
\left(2.10^{8}\right)\end{array}$ & $\begin{array}{c}569 \\
(0.33)\end{array}$ & $\begin{array}{c}845 \\
(-0.54)\end{array}$ & $\begin{array}{c}1323 \\
(0.81)\end{array}$ & $\begin{array}{c}1124 \\
\left(3.21^{8}\right)\end{array}$ & $\begin{array}{r}1570 \\
(0.57)\end{array}$ & $\begin{array}{l}11748 \\
\left(10.0^{8}\right)\end{array}$ & $\begin{array}{l}5539 \\
\left(2.49^{9}\right)\end{array}$ & $\begin{array}{l}8527 \\
\left(2.80^{3}\right)\end{array}$ & $\begin{array}{l}3754 \\
\left(2.75^{5}\right)\end{array}$ & $\begin{array}{l}4647 \\
(2.78)\end{array}$ \\
\hline $\mathrm{TFC}+\gamma \mathrm{IFN}^{\mathrm{NS}}$ & $\begin{array}{l}3552 \\
\left(6.34^{4}\right)\end{array}$ & $\begin{array}{c}310 \\
(0.11)\end{array}$ & $\begin{array}{l}4880 \\
\left(2.68^{8}\right)\end{array}$ & $\begin{array}{l}3508 \\
\left(3.82^{8}\right)\end{array}$ & $\begin{array}{l}608 \\
(0.42)\end{array}$ & $\begin{array}{l}1982 \\
(0.08)\end{array}$ & $\begin{array}{l}2745 \\
(1.55)\end{array}$ & $\begin{array}{l}1086 \\
\left(3.07^{8}\right)\end{array}$ & $\begin{array}{r}1590 \\
(0.59)\end{array}$ & $\begin{array}{l}12496 \\
\left(10.70^{8}\right)\end{array}$ & $\begin{array}{l}6859 \\
\left(3.10^{8}\right)\end{array}$ & $\begin{array}{l}8303 \\
\left(2.70^{8}\right)\end{array}$ & $\begin{array}{l}3261 \\
\left(2.26^{8}\right)\end{array}$ & $\begin{array}{l}5060 \\
(2.89)\end{array}$ \\
\hline Background 2** & 176 & 775 & 1031 & 280 & 1165 & 1453 & 903 & ND & 301 & 2156 & 257 & 105 & 250 & 257 \\
\hline Thyroid macrophages $^{N S}$ & $\begin{array}{l}1298 \\
\left(6.38^{f}\right)\end{array}$ & $\begin{array}{l}1100 \\
(0.42)\end{array}$ & $\begin{array}{c}1289 \\
(0.25)\end{array}$ & $\begin{array}{r}770 \\
(1.75)\end{array}$ & $\begin{array}{c}734 \\
(-0.37)\end{array}$ & $\begin{array}{c}1091 \\
(-0.24)\end{array}$ & $\begin{array}{l}1096 \\
(0.33)\end{array}$ & $\begin{array}{l}\text { ND } \\
\text { ND }\end{array}$ & $\begin{array}{r}842 \\
(1.80)\end{array}$ & $\begin{array}{c}1531 \\
(-0.29)\end{array}$ & $\begin{array}{c}873 \\
\left(2.40^{8}\right)\end{array}$ & $\begin{array}{c}128 \\
(0.22)\end{array}$ & 775 & 873 \\
\hline $\begin{array}{l}\text { Thyroid macrophages } \\
+\gamma \text { IFN }^{\mathrm{NS}}\end{array}$ & $\begin{array}{c}1163 \\
\left(5.61^{8}\right)\end{array}$ & $\begin{array}{l}2209 \\
(1.85)\end{array}$ & $\begin{array}{r}1309 \\
(0.27)\end{array}$ & $\begin{array}{c}1162 \\
\left(3.15^{8}\right)\end{array}$ & $\begin{array}{c}816 \\
(-0.30)\end{array}$ & $\begin{array}{l}1566 \\
(0.09)\end{array}$ & $\begin{array}{l}1365 \\
(1.06)\end{array}$ & $\begin{array}{l}\text { ND } \\
\text { ND }\end{array}$ & $\begin{array}{l}1415 \\
\left(3.70^{8}\right)\end{array}$ & $\begin{array}{r}2587 \\
(0.20)\end{array}$ & $\begin{array}{l}1058 \\
\left(3.10^{8}\right)\end{array}$ & $\begin{array}{r}130 \\
(0.24)\end{array}$ & $\begin{array}{r}787 \\
\left(2.5^{5}\right)\end{array}$ & $\begin{array}{l}1058 \\
(2.15)\end{array}$ \\
\hline
\end{tabular}

* Background 1, cpm of TFC and of PBMC cultured separately. ** Background 2, cpm of thyroid macrophages and of PBMC cultured separately. " Level of significance between disease groups $P<0.05$ (comparison of stimulation indices). Significant difference between stimulation and background $P<0.05$.

$\times 10^{4}$ TFC/culture: $518-1855 \mathrm{cpm}$, median $1051,10^{4} \mathrm{TFC} /$ culture: $207-1,214 \mathrm{cpm}$, median $552,3 \times 10^{3} \mathrm{TFC} /$ culture: 165-978, median: 2,411).

\section{Discussion}

Previous work on Graves' disease has emphasized the capacity of HLA class II expressing TFC to present antigen to autoreactive $T$ cells, which infiltrate the affected tissue $(6,7)$. However HLA class II expression on TFC has subsequently been found in diseases presumed to be nonautoimmune, such as nodular goiter (8-10). It was thus of interest to compare the immunostimulatory function of HLA class $\mathrm{II}^{+} \mathrm{TFC}$ in nontoxic nodular goiter and Graves' disease.

In accordance with earlier studies (8) HLA class II expressing TFC were present in patients with GD as well as with NTG, although the number of positive cells tended to be higher in GD than in NTG (Table I). HLA class II expression was always associated with lymphocytic infiltration, although in some of the samples very few lymphocytes were detectable. This may however be due to the fact that no serial sections

Table V. Phenotyping and Interferon-gamma Production by Intrathyroidal Lymphocytes after 4 wk Expansion with Interleukin 2 and Anti CD3 Antibody

\begin{tabular}{|c|c|c|c|c|}
\hline \multirow[b]{3}{*}{ Antibody and specificity } & \multicolumn{4}{|c|}{ \% Positive cells in $\mathrm{T}$ cell lines from } \\
\hline & \multicolumn{2}{|c|}{ Nontoxic goiter } & \multicolumn{2}{|c|}{ Graves' disease } \\
\hline & N5 & N6 & GD2 & GD4 \\
\hline OKT3 (Anti-CD3, pan T cell) & 84.5 & 92.8 & 97.3 & 96.4 \\
\hline $\begin{array}{l}\text { OKT4 (Anti-CD4, helper/ } \\
\text { inducer) }\end{array}$ & 85.2 & 77.3 & 87.2 & 61.6 \\
\hline $\begin{array}{l}\text { OKT8 (Anti-CD8, } \\
\text { suppressor/cytotoxic) }\end{array}$ & 6.2 & 21.3 & 8.6 & 29.5 \\
\hline $\begin{array}{l}\text { LEU } 11 \text { (Anti-CD16, natural } \\
\text { killer cell) }\end{array}$ & 2.5 & 7.4 & 7.9 & 2.0 \\
\hline $\begin{array}{l}\text { Interferon gamma }(\mathrm{U} / \mathrm{ml} \\
\left.\text { supernatant } / 10^{6} \text { cells }\right)\end{array}$ & 25 & 35 & 33 & 101 \\
\hline
\end{tabular}

were investigated in this study and larger lymphocytic aggregates might thus have been missed. The different degree of class II expression did not affect the in vitro induction of HLA class II antigens by IFN- $\gamma$. This confirms data by Weetman et al., who showed that IFN- $\gamma$-induced class II expression equally well on TFC from patients with GD and Hashimoto's thyroiditis as from normal controls (15).

TFC of nontoxic goiter as well as Graves' disease induced allogeneic PBMC cells to proliferate, indicating that TFC of both disorders can present alloantigens. Responses induced by

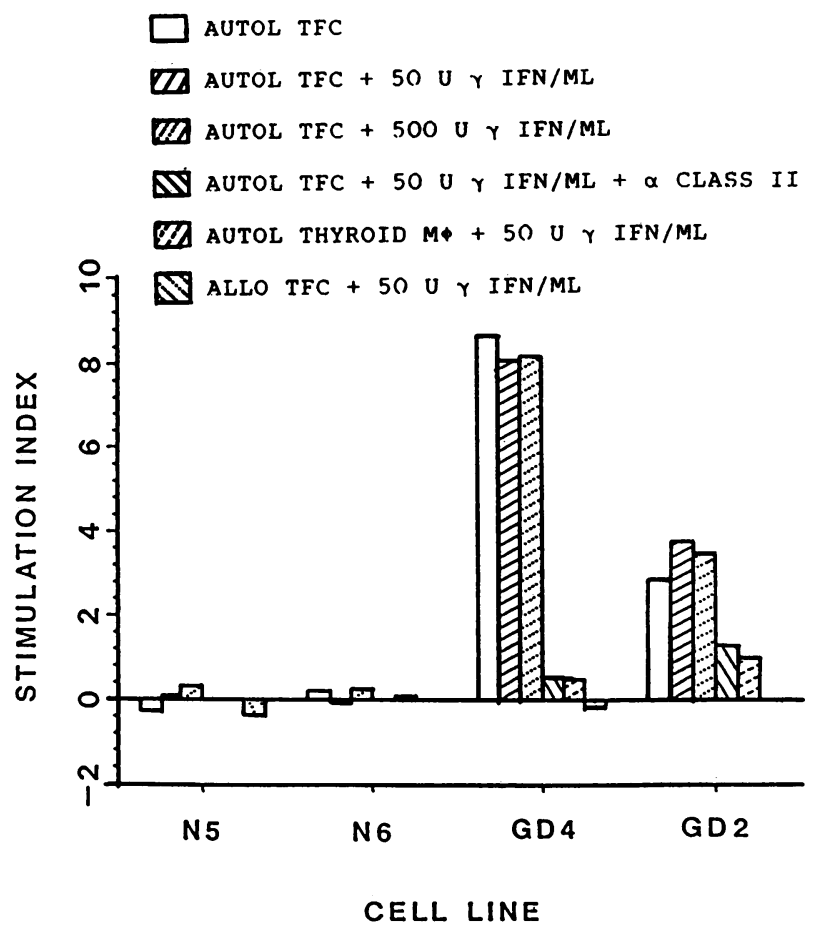

Figure 1. Specificity of intrathyroidal $\mathrm{T}$ lymphocytes after four weeks expansion with OKT3 and IL-2, from nontoxic goiter ( $T$ cell lines N5 and N6, derived from NTG patients E and F) and from Graves' disease (T cell lines GD4 and GD2, derived from GD patients $D$ and E). Proliferative responses after a 4-d co-culture of presenter and responder cells. 


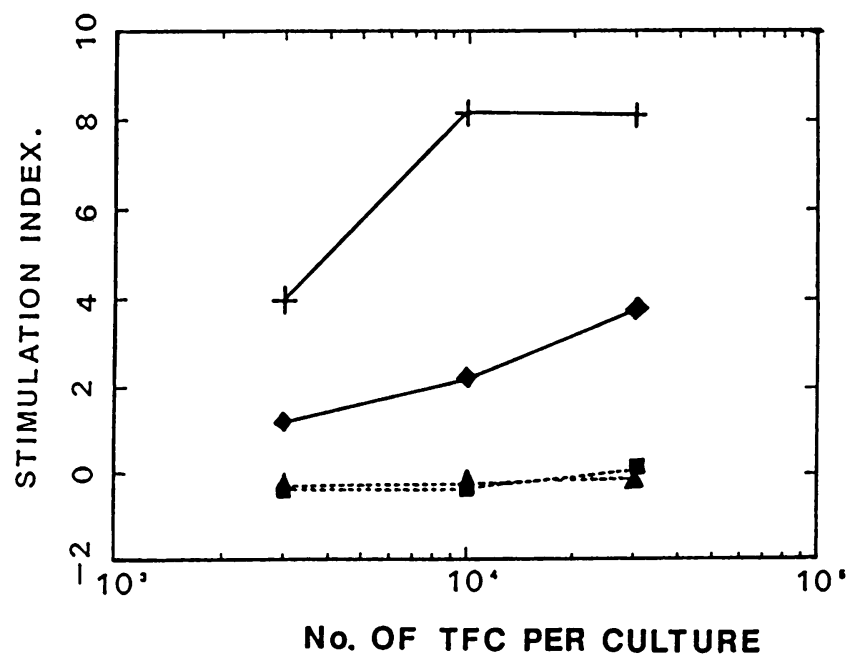

Figure 2. Responses of $\mathrm{T}$ cell lines after 4 wk expansion with OKT3 and IL-2 in nontoxic goiter ( $T$ cell lines N5, $n$, and N6, $\Delta$; derived from NTG patients $E$ and $F$ ) and in Graves' disease ( $T$ cell lines GD4, +, and GD2, ४; derived from GD patients D and E): effect of varied numbers of autologous TFC on the proliferative response of $T$ lymphocytes after a 4-d co-culture.

TFC were similar to those induced by thyroid macrophages, but weaker than the ones initiated by PBMC. This would be expected as PBMC contain very efficient antigen presenting cells, such as dendritic cells, monocytes, and B cells. In view of the relatively low basal TFC HLA class II expression in some of the NTG patients it seems surprising that significant stimulation of allogeneic PBMC was found in four of the patients. This may, however, be due to an increase in HLA class II expression induced by IFN- $\gamma$ production by the allogeneic $T$ cells during the $7 \mathrm{~d}$ of co-culture, as suggested by the work of Iwatani et al. (16). Autologous PBMC were stimulated more efficiently by GD than by NTG thyroid follicular cells. This finding is in accordance with results reported by others, who demonstrated an increase in TFC HLA class II expression during 1 wk co-culture of TFC and autologous PBMC in GD but not in NTG (16). It may indicate an abnormal sensitization of GD PBMC to autologous thyrocytes. However, IFN $\gamma$ pretreated TFC-induced proliferation of autologous PBMC in three $(50 \%)$ of the NTG patients, suggesting either, the induction of autoimmune responses against thyroid autoantigens or, more likely, the involvement of an "autologous MLR type" response against HLA class II antigens. Similar results have been reported by Davies et al. who observed that TFC from GD patients as well as lectin treated (class II expressing) normal TFC stimulated autologous peripheral T cells $(17,18)$.

Thyroid infiltrating $\mathrm{T}$ cells were screened for their capacity to respond to autologous TFC. Due to the limited number of cells available these cannot be tested directly, and so were cultured with OKT3 and IL-2 to initiate growth nonspecifically, by using a variation of a published method (14). It is noteworthy that only the $\mathrm{T}$ cells from GD responded to autologous TFC (Figs. 1 and 2). As for GD PBMC, stimulation could not be further increased by preincubation of TFC with IFN- $\gamma$. This may be due to the fact that in GD HLA class II antigens were already expressed at a high level in vivo and might still have been further induced by IFN- $\gamma$ secreted during co-culture with lymphocytes (16). The lack of reactivity of cultured intrathyroidal T lymphocytes to autologous IFN- $\gamma$ treated thyroid macrophages excludes the possibility that HLA class II-specific T cells of the autologous MLR type are responsible for the effect observed in GD. However, responses could be blocked with anti-HLA class II antibodies, which demonstrates that HLA class II expression on TFC is a necessary requirement for the presentation of thyroid autoantigens in GD.

The lack of autoantigen recognition by the $\mathrm{T}$ cell lines derived from NTG thyroid glands suggests strongly that NTG is not an autoimmune disease and indicates that HLA class II expression on TFC is by itself not sufficient for the induction of autoimmune responses. Thyroid lymphocytic infiltration seems to be nonspecific in NTG and may be regarded as a correlate of nonspecific local inflammatory reactions, which have been demonstrated to take place in NTG as a consequence of growth induced tissue damage (19). As T cell lines expanded from NTG thyroids secrete similar amounts of IFN- $\gamma$ in vitro as lines derived from GD thyroids, it seems likely that, in vivo, $\mathrm{T}$ lymphocytes infiltrating NTG may produce IFN- $\gamma$ locally, and thus induce expression of HLA class II antigens in NTG TFC (20). It can thus be assumed that the class II expression on TFC noted in autoimmune thyroid disease and subacute thyroiditis (21) is due to IFN $\gamma$ released locally by infiltrating lymphocytes (16).

It is interesting that two NTG patients had low titer thyroid autoantibodies in spite of a total lack of $\mathrm{T}$ lymphocytic autoantigen recognition. This may indicate that local inflammatory reactions in the thyroid gland, although nonspecific per se may, via a leakage of thyroid antigens, still result in B cell activation and subsequent autoantibody production.

The validity of our assumptions is obviously dependent on the fact that the stimulatory effects observed are induced by the TFC themselves and not by contaminating cells such as dendritic cells and macrophages. However dendritic cells, which have been considered to be of importance as intrathyroidal antigen presenters in thyroid disease (22), are not adherent after $24 \mathrm{~h}$ incubation $(23,24)$ and thus of no influence in our system. Macrophage contamination was estimated by immunostaining with $\alpha$ LeuM3 and by microscopic examination and was $<2 \%$. As TFC expressing class II induce similar proliferation of allogeneic PBMC as HLA class $\mathrm{II}^{+}$thyroid macrophages $\left(64 \%\right.$ LeuM $^{+}$) it seems evident that the stimulatory effect of the TFC population is induced by the TFC themselves.

Our results thus demonstrate that in spite of the similar alloantigen presenting capacity of NTG and GD TFC, thyroid autoantigen presentation by HLA class $\mathrm{II}^{+}$TFC occurs only in GD, but not in NTG. The two diseases thus do not share a common autoimmune background. HLA class II expression on TFC is a necessary requirement, but by itself not sufficient for the induction of autoimmune disease.

What are the other necessary components to the development of thyroid autoimmunity? Currently this is not understood in detail. Evidence suggesting that autoimmune thyroid disease is due to a genetically determined organ specific defect in suppressor $\mathrm{T}$ lymphocytes has recently been reviewed by Volpé (25). The fact that thyroid autoimmune disease is HLA-DR associated (26) further suggests that the polymorphic part of HLA class II contributes toward susceptibility to autoimmunity. Since the function of the polymorphic components of HLA class II is the presentation of antigen to $T$ cell 
receptors, and since autoimmune diseases have a multigenic predisposition extending beyond HLA class II (27) it is tempting to speculate that the presence of the appropriate $T$ cell receptors is also necessary for the development of autoimmune disease such as Graves' disease. This is currently under investigation.

\section{Acknowledgments}

We are grateful to the scientists and firms cited in the text for their generous donations of reagents. We thank Dr. Macrail for statistical advice and Mrs. P Wells and Miss M Burke for preparing the manuscript.

Supported by the Fonds zur Forderung der wissenschaftlichen Forschung, Austria (Erwin Schrodinger Scholarship), by the Wellcome Trust, and by Juvenile Diabetes Foundation International.

\section{References}

1. Schwartz, R. H. 1985. T lymphocyte recognition of antigen in association with gene products of the major histocompatibility complex. Annu. Rev. Immunol. 3:237-263.

2. Germain, R. N. 1986. The ins and outs of antigen presentation. Nature (Lond.). 322:687-689.

3. Hanafusa, T., L. Chiovato, D. Doniach, R. Pujol-Borrell, R. C. G. Russell, and G. F. Bottazzo. 1983. Aberrant expression of HLA-DR antigen on thyrocytes in Graves' disease: relevance for autoimmunity. Lancet. ii:1111-1115.

4. Bottazzo, G. F., R. Pujol-Borrell, T. Hanafusa, and M. Feldmann. 1983. Hypothesis: Role of aberrant HLA-DR expression and antigen presentation in the induction of endocrine autoimmunity. Lancet. ii:1115-1116.

5. Londei, M., J. R. Lamb, G. F. Bottazzo, and M. Feldmann. 1984. Epithelial cells expressing aberrant MHC class II determinants can present antigen to cloned human T cells. Nature (Lond.). 312:639-641.

6. Londei, M., G. F. Bottazzo, and M. Feldmann. 1985. Human T cell clones from autoimmune thyroid glands: specific recognition of autologous thyroid cells. Science (Wash. DC). 228:85-89.

7. Weetman, A. P., D. J. Volkman, K. D. Burman, J. B. Margolick, P. Petrick, B. D. Weintraub, and A. S. Fauci. 1986. The production and characterization of thyroid-derived $\mathrm{T}$ cell lines in Graves' disease and Hashimoto's thyroiditis. Clin. Immunol. Immunopathol. 39:139150.

8. Grubeck-Loebenstein, B., K. Derfler, H. Kassal, W. Knapp, K. Krish, K. Liszka, P. P. A. Smith, and W. Waldhäusl. 1985. Immunological features of nonimmunogenic hyperthyroidism. J. Clin. Endocrinol. Metab. 60:150-155.

9. Grubeck-Loebenstein, B., H. Kassal, P. P. A. Smyth, K. Krisch, and W. Waldhäusl. 1986. The prevalence of immunological abnormalities in endemic simple goitre. Acta Endocrinol (Copenhagen). 113:508-513.

10. Pujol-Borrell, R., A. Lucas Martin, M. Fox, I. Todd, and G. F. Bottazzo. 1986. Inappropriate HLA class II expression in a wide variety of thyroid diseases. J. Endocrinol. Invest. 9(Suppl. 3):71 (Abstr.).

11. Lloyd, R. V., T. L. Johnson, M. Blaivas, J. C. Sisson, and B. S. Wilson. 1985. Detection of HLA-DR antigens in paraffin-embedded thyroid epithelial cells with a monoclonal antibody. Am. J. Pathol. 120:106-111.

12. Roitt, I. M., and D. Doniach. 1960 . Thyroid autoimmunity. Br. Med. Bull. 16:152-158.

13. Schade, R. O. K., S. G. Owen, G. A. Smart, and R. Hall. 1960. The relation of thyroid autoimmunity to round celled infiltration of the thyroid gland. J. Clin. Pathol. 13:499-501.

14. Padula, S. J., M. K. Pollard, E. G. Lingenheld, and R. B. Clark. 1985. Maintenance of antigen specificity by human interleukin-2-dependent $\mathrm{T}$ cell lines, use of antigen presenting cells and OKT3 antibody in the absence of antigen. J. Clin. Invest. 75:788-797.

15. Weetman, A. P., D. J. Volkman, K. D. Burman, T. L. Gerrard, and A. S. Fauci. 1985. The in vitro regulation of human thyrocyte HLA-DR antigen expression. J. Clin. Endocrinol. Metab. 61:817-824.

16. Iwatani, Y., H. C. Gerstein, M. litaka, V. V. Row, and R. Volpé. 1986. Thyrocyte HLA-DR expression and interferon- $\gamma$ production in autoimmune thyroid disease. J. Clin. Endocrinol. Metab. 63:695-708.

17. Davies, T. F., B. Bermas, M. Platzer, and S. H. Roman. 1985. T cell sensitization to autologous thyroid cells and normal non-specific suppressor T cell function in Graves' disease. Clin. Endocrinol. (Oxf.). 22:155-159.

18. Davies, T. F. 1985. Coculture of human thyroid monolayer cells and autologous T cells: impact of HLA class II antigen expression. J. Clin. Endocrinol. Metab. 61:418-422.

19. Gebel, F., F. Ramelli, U. Burgi, U. Ingold, H. Studer, and R. Winand. 1983. The site of leakage of intrafollicular thyroglobulin into the blood stream in simple human goitre. J. Clin. Endocrinol. Metab. 57:915-919.

20. Todd, I., R. Pujol-Borrell, L. J. Hammond, G. F. Bottazzo, and M. Feldmann. 1985. Interferon- $\gamma$ induces HLA-DR expression by thyroid epithelium. Clin. Exp. Immunol. 61:265-273.

21. Leclere, J., G. Faure, M.-C. Bene, J.-L. Thomas, J.-L. Paul, and P. Hartemann. 1986. In situ immunologic disorders in de Quervain's thyroiditis. In Frontiers in Thyroidology. G. Mederios-Neto and E. Gaitan, editors. Plenum Publishing Corp., New York and London. 1365-1368.

22. Voorbij, H. A. M., P. J. Kabel, and H. A. Drexhage. 1986. Antigen presenting cells (APCs) and thyroid autoimmune response in the BBW rat. In The Thyroid and Autoimmunity. H. A. Drexhage and W. M. Wiersinga, editors. Elsevier Science Publishers B.V., Amsterdam. 166-169.

23. Steinman, R. M. 1986. Dendritic cells: contribution to cell mediated immunity. In The Thyroid and Autoimmunity. H. A. Drexhage and M. Wiersinga, editors. Elsevier Science Publishers, B.V., Amsterdam. 153-163.

24. Knight, S. C., J. Farrant, A. Bryant, A. J. Edwards, S. Burman, A. Lever, J. Clarke, and A. D. B. Webster (1986) Nonadherent, lowdensity cells from human peripheral blood contain dendritic cells and monocytes, both with veiled morphology. Immunology. 57:595-603.

25. Volpé, R. 1986. Autoimmune thyroid disease-a perspective. Mol. Biol. Med. 3:25-51.

26. Farid, N. R., and J. C. Bear. 1983. Autoimmune endocrine disorders and the major histocompatibility complex. In Autoimmune Endocrine Disease. T. F. Davies, editor. John Wiley \& Sons, Inc., New York. 58-65.

27. Strominger, J. L. 1986. Biology of the human histocompatibility leukocyte antigen (HLA) system and a hypothesis regarding the generation of autoimmune diseases. J. Clin. Invest. 77:1411-1415. 